\title{
Association of Blood Group Antigen CD59 with Disease
}

\author{
Christof Weinstock \\ German Red Cross Blood Service Baden-Württemberg - Hessen, Institute Ulm, Ulm, Germany; Institute for Clinical \\ Transfusion Medicine and Immunogenetics Ulm, Ulm, Germany; Institute of Transfusion Medicine, Ulm University, \\ Ulm, Germany
}

\section{Keywords}

CD59 · Blood group · Deficiency · Disease

\section{Abstract}

In 2014, the membrane-bound protein CD59 became a blood group antigen. CD59 has been known for decades as an inhibitor of the complement system, located on erythrocytes and on many other cell types. In paroxysmal nocturnal haemoglobinuria (PNH), a stem cell clone with acquired deficiency to express GPI-anchored molecules, including the complement inhibitor CD59, causes severe and life-threatening disease. The lack of CD59, which is the only membrane-bound inhibitor of the membrane attack complex, contributes a major part of the intravascular haemolysis observed in $\mathrm{PNH}$ patients. This crucial effect of CD59 in $\mathrm{PNH}$ disease prompted studies to investigate its role in other diseases. In this review, the role of CD59 in inflammation, rheumatic disease, and age-related macular degeneration is investigated. Further, the pivotal role of CD59 in PNH and congenital CD59 deficiency is reviewed.

(C) 2022 The Author(s).

Published by S. Karger AG, Basel

\section{Introduction}

A heritable molecule on the membrane of erythrocytes becomes a blood group antigen as soon as a person, who does not carry the identical molecule or the molecule at all, produces antibodies against (epitopes of) the said molecule. Transfusion medicine focuses on the difficulties in serological diagnostics and on provision of compatible erythrocyte units, but for most of these molecules, being a blood group antigen is only a side job. They have major functions in erythrocyte physiology by acting as transporter proteins (e.g., RH [1], JK [2], CO [3], LAN [4], JR [5]), receptors for mediators (e.g., FY [6]), enzymes (e.g., KEL [7], YT [8]), or adhesion molecules (e.g., LU [9]). Variation or deficiency of a blood group antigen can cause erythrocyte malfunction or disease. Causing systemic disease is likely when a blood group antigen is not restricted to erythrocytes but is also present on other cells and tissues. The blood group antigen CD59 blocks the completion of the membrane attack complex on host cells and protects them from unwanted and uncontrolled lysis by the complement system [10]. It is the only membrane-bound inhibitor of the terminal pathway of the complement system; no other molecule providing a backup function exists. CD59 protein variants with impaired function have not been described so far [11-15]. Low density of membrane-anchored CD59 was thought to generate unprotected areas on the cell membrane, which expose the cells or tissues to complement-mediated damage, a concept that has been deduced from paroxysmal nocturnal haemoglobinuria (PNH) where the lack of CD59 on PNH cells causes disease $[16,17]$. Published knowledge on the role of CD59 in disease will be investigated in the following.

\section{The Blood Group System CD59}

In the blood sample of a 2-year-old girl suffering from a severe neurological disease which was accompanied by recurrent haemolytic episodes, an antibody was found re-

\section{karger@karger.com} www.karger.com/tmh

Karger ${ }^{\prime \prime}=$

BOPEN ACCESS (c) 2022 The Author(s)

Published by S. Karger AG, Basel

This article is licensed under the Creative Commons Attribution 4.0 International License (CC BY) (http://www.karger.com/Services/ OpenAccessLicense). Usage, derivative works and distribution are permitted provided that proper credit is given to the author and the original publisher.
Correspondence to:

Christof Weinstock, c.weinstock@blutspende.de 
Table 1. Variants of the CD59 gene and their phenotypes

\begin{tabular}{|c|c|c|c|c|c|c|}
\hline ISBT variant No. & $\begin{array}{l}\text { Genetic } \\
\text { variant }\end{array}$ & $\begin{array}{l}\text { dbSNP } \\
\text { numbers }\end{array}$ & $\begin{array}{l}\text { Effect on } \\
\text { protein }\end{array}$ & Expression of CD59 & $\begin{array}{l}\text { Test } \\
\text { used }\end{array}$ & Reference \\
\hline CD59*01N.01 & c. $146 \mathrm{del}^{\dagger}$ & rs587777149 & p.Asp49Valfs*31 $*$ & $\begin{array}{l}\text { Erythrocytes: no } \\
\text { Granulocytes: no } \\
\text { Post-mortem brain tissue: no } \\
\text { Erythrocytes: no }\end{array}$ & $\begin{array}{l}\text { FCM } \\
\text { IHCS } \\
\text { FCM }\end{array}$ & $\begin{array}{l}{[12]} \\
{[110]} \\
{[112]}\end{array}$ \\
\hline CD59*01N.02 & $\begin{array}{l}\text { c.123delC } \\
\text { c.361delG }\end{array}$ & n.a. & $\begin{array}{l}\text { p.Val42Serfs*38 } \\
\text { n.a. }\end{array}$ & $\begin{array}{l}\text { Erythrocytes: no } \\
\text { Fibroblasts: no } \\
\text { EBV-transformed lymphoblastoid cells: no }\end{array}$ & FCM & {$[25]$} \\
\hline CD59*01N03 & c. $266 \mathrm{G}>\mathrm{A}$ & rs397514767 & p.Cys89Tyr & $\begin{array}{l}\text { Erythrocytes and mononuclear cells: no } \\
\text { Epineural blood vessel endothelium: no }\end{array}$ & $\begin{array}{l}\text { FCM } \\
\text { IHCS }\end{array}$ & {$[108,109]$} \\
\hline CD59.01N04 & c. $146 \mathrm{~A}>\mathrm{T}$ & n.a. & p.Asp49Val & $\begin{array}{l}\text { Erythrocytes: no } \\
\text { (Cell type not given: no) }\end{array}$ & $\begin{array}{l}\text { FCM } \\
\text { FCM }\end{array}$ & $\begin{array}{l}{[13]} \\
{[111]}\end{array}$ \\
\hline Not yet registered & c. $323 \mathrm{C}>\mathrm{A}$ & rs749308157 & p.Ser108Ter & Lymphocytes: no & FCM & [14] \\
\hline Not yet registered & $\mathrm{c} .85 \mathrm{~T}>\mathrm{G}$ & rs1564972905 & p.Tyr29Asp & $\begin{array}{l}\text { Erythrocytes: }<1 \% \\
\text { Lymphocytes, granulocytes, platelets: no }\end{array}$ & FCM & {$[15]$} \\
\hline CD59*01.02prov. & c. $238 \mathrm{~A}>\mathrm{G}$ & n.a. & p.Arg80Gly & $\begin{array}{l}\text { Erythrocytes: yes } \\
\text { Normal density }\end{array}$ & FCM & {$[24]$} \\
\hline
\end{tabular}

ISBT, International Society of Blood Transfusion; dbSNP, database of Short Genetic Variations; FCM, flow cytometry; IHCS, immunohistochemical staining; n.a., not available. ${ }^{\dagger}$ National Center for Biotechnology Information (NCBI) mRNA reference sequence used for naming the genetic variant is NM_203330.2. ${ }^{\ddagger} \mathrm{NCBI}$ protein reference sequence used for naming the amino acid variation is NP_976075.1.

acting with all reagent cells [18]. The patient had been transfused previously, which made the presence of an immune antibody possible, but the specificity of this antibody could not be identified. It took several months until the diagnosis "congenital CD59 deficiency" gave the important clue, and in the year 2012, targeted serological investigation confirmed the presence of an antibody with the specificity "anti-CD59."

The Working Party Red Cell Immunogenetics and Blood Group Terminology of the International Society of Blood Transfusion (ISBT) defines an erythrocyte antigen as a blood group antigen if a subject has made an antibody directed against this antigen [19]. A blood group system is defined as 1 or more blood group antigens governed by 1 gene or several closely linked genes [19]. In 2014, the membrane protein CD59 was acknowledged as a new blood group system. The system received the number 035, and it comprises 1 antigen so far, which was denoted CD59.1 [20].

\section{CD59 Gene and Protein}

The CD59 gene (HGNC: 1689; Entrez Gene: 966; LRG_41) is located on chromosome 11p13. Several sequences had been deposited at the National Center for Biological Information database; the ISBT acknowledged sequence NG_008057.1 as a reference sequence for CD59.
The gene comprises 6 exons which are all present in the transcript variant 1 (NM_203330.2). Additional transcript variants combining different exons are deposited in the database, but all include exons 4,5 , and 6 , which contain the coding sequence [21]. The mRNA is translated into a pre-proprotein consisting of 128 amino acids. During the processing of the pre-proprotein to the final, membrane-bound protein, 25 amino acids are cleaved from the amino terminus, and 28 amino acids from the carboxy terminus are cleaved when the glycosylphospatidylinositol (GPI) anchor is generated [22].

\section{CD59 Alleles and Phaenotypes}

The girl with the CD59 deficiency was homozygous for the deletion of a cytosine at position c.146, which caused a shift of the reading frame and introduced a pre-terminal stop codon (Table 1). Flow cytometry confirmed the lack of CD59 on erythrocytes and leucocytes [12]. Additional genetic variants causing CD59 deficiency were reported (Table 1). Some of these variants carry a premature stop codon, other variants cause a single amino acid substitution. The changes in the CD59 protein introduced by these single amino acid substitutions were crucial for the expression of the protein because all the patients were tested negative for CD59 and were severely ill. The lack of CD59 expression 


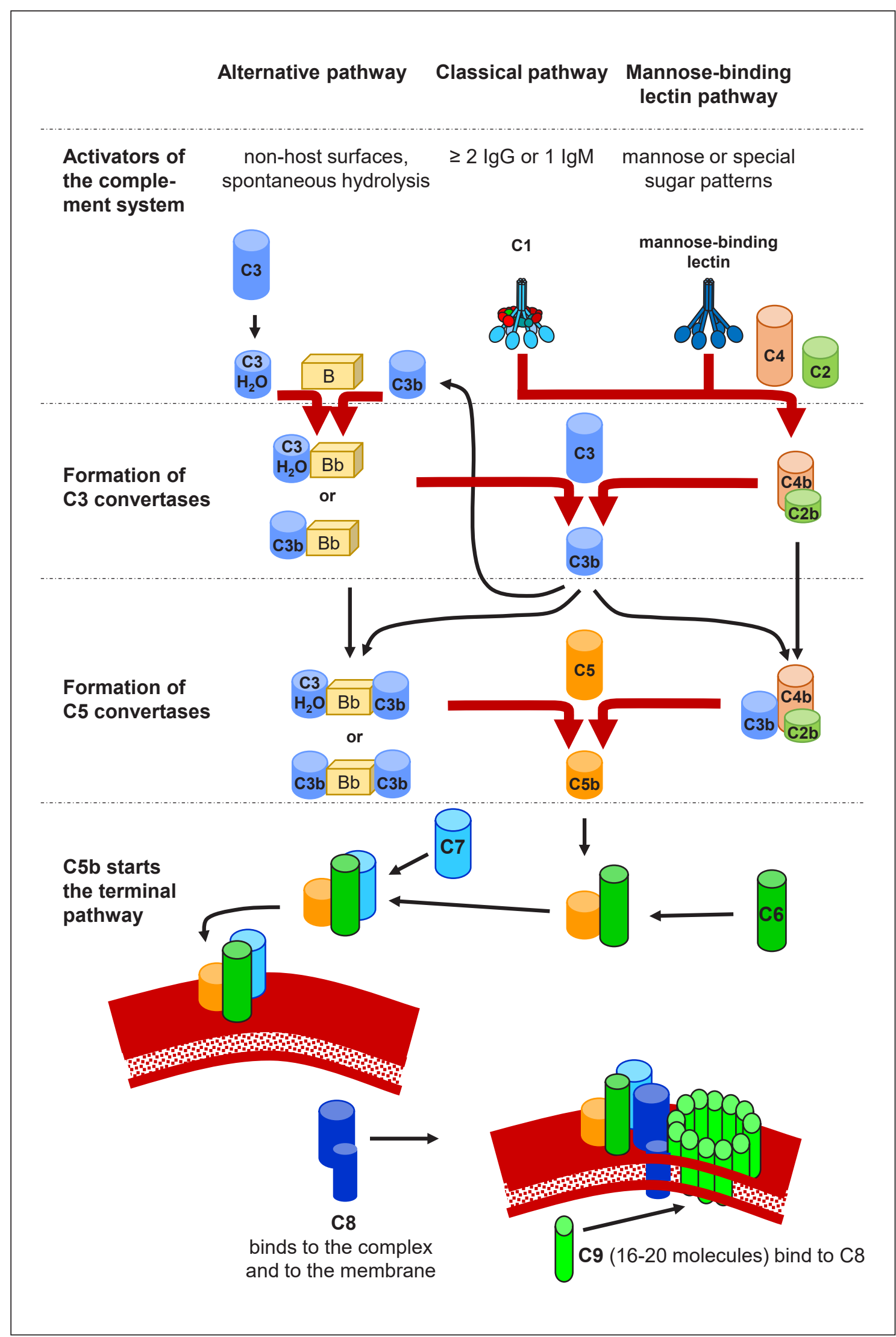

Fig. 1. A simplified depiction of the activation pathways of the complement system. C1-C9 denote the complement components 1-9, B denotes complement factor $\mathrm{B}$. $\mathrm{C}_{3} \mathrm{H}_{2} \mathrm{O}$ denotes the hydrolysed form of $\mathrm{C} 3$. The letter " $\mathrm{b}$ " indicates an activated component or factor. Fat arrows indicate the enzymatic cleavage of a component or factor. The cleaved parts of the complement components (e.g., C3a) are not shown for reasons of simplicity. 
wasconfirmed for thevariantsc.146delA (p.Asp49Valfs*31), c.123delC (p.Val42Serfs*38), c.266G>A (p.Cys89Tyr), and c.146A $>$ T (p.Asp49Val) in transfection studies [23]. Four alleles were acknowledged by the ISBT as null alleles [20].

In a healthy propositus, the single nucleotide variation c. $238 \mathrm{~A}>\mathrm{G}$ (p.Arg80Gly) was detected in heterozygosity [24]. This variant also caused an amino acid exchange which, in contrast, did neither impair the expression of the variant CD59 protein, nor did it impair the cognate epitope recognition by the fluorescent-labelled antiCD59 antibodies used in flow cytometry. The erythrocytes of this propositus showed the same CD59 density as did controls homozygous for the wild-type allele [24]. In contrast, propositi heterozygous for the null alleles c.146delA [18] or c.123delC [25] showed markedly decreased expression of CD59. No data on functionality of this CD59 protein variant are available.

\section{Activation and Inhibition of the Complement System}

\section{Pathways of Complement Activation}

The complement system can be activated by 3 pathways which all lead to the assembling of the membrane attack complex (MAC). Antibodies bound to their cognate antigen can activate $\mathrm{C} 1$, the first component of the complement system (Fig. 1). Activated C1 activates the components $\mathrm{C} 4$ and $\mathrm{C} 2$, which form the bimolecular complex C4bC2b, which functions as a C3 convertase (classical pathway of complement activation). The mannosebinding lectin (MBL) recognises mannose and certain other sugars, arranged in a special pattern (reviewed in [26]). Binding to the recognition patterns activates MBL, which now can activate $\mathrm{C} 4$ and $\mathrm{C} 2$ to form the $\mathrm{C} 3$ convertase of the lectin pathway, which is identical to the classical pathway convertase. The $\mathrm{C} 3$ convertases initiated by these 2 pathways convert a large number of C3 molecules into their activated form $\mathrm{C} 3 \mathrm{~b}$. $\mathrm{C} 3$ also activates itself by spontaneous hydrolysis ("tick over"), yielding $\mathrm{C} 3\left(\mathrm{H}_{2} \mathrm{O}\right)$, which has similar functionality as $\mathrm{C} 3 \mathrm{~b}$. $\mathrm{C} 3\left(\mathrm{H}_{2} \mathrm{O}\right)$ or $\mathrm{C} 3 \mathrm{~b}$ together with factor $\mathrm{B}$ covalently bind to cell membranes, forming the bimolecular $\mathrm{C} 3$ convertase of the alternative pathway $\mathrm{C} 3 \mathrm{bBb}$ (or $\mathrm{C} 3 \mathrm{H}_{2} \mathrm{OBb}$, respectively). $\mathrm{C} 5$ is sequestered to this surface and converted into $\mathrm{C} 5 \mathrm{a}$ and $\mathrm{C} 5 \mathrm{~b}$, which initiates the terminal pathway $[27,28]$. Nascent C5b binds the complement components $\mathrm{C} 6-\mathrm{C} 8$ and multiple $\mathrm{C} 9$ molecules forming the MAC pore (Fig. 1).

\section{CD59 and Other Membrane-Bound Inhibitors of Complement}

Several soluble and membrane-bound inhibitors and activators balance the complement system. They take care that the activation of the complement system normally stays localised [29]. In addition, they protect the host's cells from an unwanted destruction by their own complement [30]. Ideally, the complement cascade should be activated on intruders' surfaces only, but activated complement components, especially C3b, spread onto the surrounding host cells ("innocent bystanders") with the risk of amplifying the alternative pathway by assembling more convertases, which eventually could start the terminal pathway. The membrane-bound complement regulators complement receptor 1 (CR1; CD35) [31] and decay-accelerating factor (DAF; CD55) [32] inhibit the convertases by displacing the activated proteolytic units of the convertases. CR1 and membrane cofactor protein (MCP; CD46) [33] support the cleavage of membrane-bound C3b by complement factors I and $\mathrm{H}$. All these inhibitors and cofactors downregulate complement activation at the level of C3 convertase or C5 convertase. The membranebound protein CD59 inhibits the formation of the MAC. CD59 inclines towards the assembling C5-C8 and C5-C9 complexes, binds to C8 and C9 [34] and interferes with the polymerisation of the C9 molecules. Thereby, CD59 prevents the assembly of the MAC. CD59 is the only membrane-bound inhibitor that blocks MAC assembly.

\section{Tissue Distribution of CD59}

CD59 being the only inhibitor of the MAC implies that all kinds of cells and tissues, which come into contact with the complement system, express CD59. CD59 was detected by flow cytometry, immunohistochemistry, or immunocytochemistry on numerous cell types (Table 2). Best known is the presence of CD59 on erythrocytes and leucocytes, but CD59 was also found on platelets [35] and dendritic cells [36]. Cells of the central and peripheral nervous system express CD59, including brain parenchyma [37], neurons [38-40], chorioid plexus epithelium [37, 39], ependymal cells [41], Schwann cells [41, 42], and retinal pigment epithelium (RPE) [43, 44]. CD59 is present on the endothelium of arteries, veins, and capillaries [41, 45-47], glomerular endothelium, glomerular epithelium, mesangial cells [41] and podocytes [48]. CD59 was found on gingival epithelium [49], epithelium of the salivary gland [41], thyroid follicular cells [50], bronchial epithelium [41], squamous epithelium [41, 47], keratinocytes [51], chondrocytes [52], synovia [53], muscle cells [54], amniotic cells [55], and extravillous trophoblast [56].

\section{CD59 Expression in Inflammation and Infectious Disease}

Surface structures of bacteria and viruses can activate the human complement system via the alternative pathway or the lectin pathway. Antibodies binding to bacteria 
Table 2. Tissue distribution of CD59

\begin{tabular}{|c|c|c|}
\hline Blood cells & $\begin{array}{l}\text { Erythrocytes } \\
\text { Leucocytes } \\
\text { Platelets } \\
\text { Dendritic cells }\end{array}$ & $\begin{array}{l}{[114]} \\
{[115]} \\
{[35]} \\
{[36]}\end{array}$ \\
\hline Nervous system & $\begin{array}{l}\text { Brain parenchyma } \\
\text { Neurons } \\
\text { Chorioid plexus epithelium } \\
\text { Ependymal cells } \\
\text { Schwann cells } \\
\text { Retinal pigment epithelium }\end{array}$ & $\begin{array}{l}{[37]} \\
{[38-40]} \\
{[37,39]} \\
{[41]} \\
{[41,42]} \\
{[43,44]}\end{array}$ \\
\hline Blood vessel endothelium & $\begin{array}{l}\text { Arteries } \\
\text { Veins } \\
\text { Capillaries }\end{array}$ & $\begin{array}{l}{[41]} \\
{[41,45,46]} \\
{[41,45,46]}\end{array}$ \\
\hline Kidney & $\begin{array}{l}\text { Glomerular endothelium } \\
\text { Glomerular epithelium } \\
\text { Mesangial cells } \\
\text { Podocytes }\end{array}$ & $\begin{array}{l}{[41]} \\
{[41]} \\
{[41]} \\
{[48]}\end{array}$ \\
\hline Glands & $\begin{array}{l}\text { Salivary gland } \\
\text { Thyroid follicular cells }\end{array}$ & $\begin{array}{l}{[41]} \\
{[50]}\end{array}$ \\
\hline Skin & $\begin{array}{l}\text { Squamous epithelium } \\
\text { Keratinocytes }\end{array}$ & $\begin{array}{l}{[41,47]} \\
{[51]}\end{array}$ \\
\hline Bronchial epithelium & & {$[41]$} \\
\hline Gingival epithelium & & [49] \\
\hline Joints, muscles & $\begin{array}{l}\text { Chondrocytes } \\
\text { Synovia } \\
\text { Muscle cells }\end{array}$ & $\begin{array}{l}{[52]} \\
{[53]} \\
{[54]}\end{array}$ \\
\hline Placental tissue & $\begin{array}{l}\text { Amniotic cells } \\
\text { Extravillous trophoblast }\end{array}$ & $\begin{array}{l}{[55]} \\
{[56]}\end{array}$ \\
\hline
\end{tabular}

and viruses activate the classical pathway. A large number of C3b molecules may spread onto the surrounding tissues and nearby cells, ready to build a C5 convertase and activate the MAC. CD59 protects the cells from lysis by the MAC, but this protection is not absolute as we know from the transfusion of $\mathrm{ABO}$-incompatible erythrocytes [57]. If the activation of the MAC is massive, protection by CD59 can be overrun and cells will be damaged. From the perspective of the host, it would be favourable if endothelial cells and the cells in the neighbourhood of a local infection or inflammation could upregulate the number of CD59 molecules on their membranes. Lipopolysaccharide (LPS) from the cell wall of gram-negative bacteria, for example, can directly upregulate CD59 expression on human monocytes [58] and on oral epithelial cells [59]. Another important regulator of CD59 is the C-reactive protein (CRP), an acute-phase protein that increases in plasma during inflammation. In a computational analysis of 491 individuals of the Estonian biobank cohort, high CRP levels were strongly correlated with activation of the CD59 gene in leucocytes [60]. The authors additionally performed cell culture experiments and confirmed that
CRP upregulates CD59 expression in peripheral leucocytes. CRP is part of a network of mediators, which regulate CD59 expression: CRP is produced by the liver upon stimulation by interleukin-6 (IL-6). IL-6 is produced by monocytes and other cells in infection and inflammation, for example upon stimulation by LPS. LPS-stimulated monocytes in addition release IL-1 and tumour necrosis factor alpha (TNF- $\alpha$ ). These and other pro-inflammatory cytokines can directly upregulate CD59 expression: TNF- $\alpha$ and IL- 1 upregulated the expression of CD59 in colon carcinoma cell lines [61] and in a hepatoma cell line [62], but not in keratinocytes [51]. In endothelial cells, TNF- $\alpha$ upregulated CD59, but IL-1 downregulated CD59 expression [63]. Interferon gamma (IFN- $\gamma$ ) upregulated CD59 in colon cancer cells when used in low dose [61], but not with regular concentrations $[61,64]$. In hepatoma cells, IFN- $\gamma$ strongly antagonised CD59 upregulating effects of TNF- $\alpha$ or IL-1 [62]. Not only pro-inflammatory but also anti-inflammatory cytokines upregulated the expression of CD59: IL-10 was found to upregulate CD59 on monocytes [65]. These in part contradicting results need further investigations. It is likely that different experimental conditions had an impact on the cytokine secretion in these in vitro experiments. In addition, different kinds of cells or tissues indeed may show individual reaction patterns.

\section{CD59 and Rheumatoid Arthritis}

Rheumatoid arthritis is associated with chronic inflammation of peripheral joints. The synovial lining is infiltrated with leucocytes and, with progress of the disease, synovial cells will form the pannus, a tissue that invades and destroys the structures of the bone and the cartilage of the joint. Pro-inflammatory cytokines, immune complexes and elevated levels of complement components are present in the synovial fluid [66]. Complement and CD59 were discussed to play a role in rheumatoid arthritis and in other forms of arthritis [67-69]. These findings triggered experiments in animal models investigating the role of the MAC and of CD59 in arthritis. When osteoarthritis and synovitis were induced by trauma, mice deficient in C6, a component of the MAC, were protected against arthritis [70]; mice deficient in CD59 developed more severe arthritis and synovitis [70] or rheumatoid arthritis [71] than wild-type mice. In rat models, intraarticular blocking of CD59 by injection of a monoclonal anti-CD59 $\mathrm{F}(\mathrm{ab})_{2}$ caused acute arthritis [72], whereas intra-articular administration of rat CD59 suppressed rheumatoid disease [73]. In one in vitro study, statins upregulated CD59 expression on endothelial cells cultured under hypoxic conditions, and the authors speculated that by this mechanism, statins exert an anti-inflammatory effect in rheumatoid arthritis [74]. In vivo studies in humans are missing so far. 


\section{CD59 and Age-Related Macular Degeneration}

Age-related macular degeneration (AMD) is the most common cause of blindness in industrialized nations [75]. Atrophic changes of the RPE and photoreceptors cause progressive loss of vision. The cause and the pathogenesis of AMD are not well understood. Risk factors are age, genetic predisposition, oxidative stress and smoking [76]. Accumulation of oxidative damage and inflammation are thought to injure the retinal cells [77]. With normal ageing, increasing numbers of so-called drusen can be found in the retina: deposits of lipids and proteins (lipofuscin) between the cells of the RPE and the Bruch's membrane [78]. In addition to the expected age-related, smaller $(<63 \mu \mathrm{m})$ drusen, increased numbers of large $(>125 \mu \mathrm{m})$ drusen were found in AMD patients [79]. Drusen contain complement proteins and CD59 protein [80], and choroid cells carry complement proteins including the MAC on their surface [79], implicating a role for the complement system in the pathogenesis of AMD [81]. In 2005, several groups identified a common variation of complement factor $\mathrm{H}, \mathrm{Y} 402 \mathrm{H}$, as a risk for AMD [82-84]. It was discussed that the variant factor $\mathrm{H}$ might be less efficient in inhibiting activated C3 molecules bound to the cell membrane and, thereby, allows increased formation of MAC. MAC deposition on the RPE and the choriocapillaris causes damage to these cells and promotes the development of AMD [84]. Cells of the RPE in AMD-affected regions of the retina showed a markedly decreased expression of CD59 [80]. Exogenous triggers such as oxidative stress [43] or oxidised lipoproteins [80] can cause the retinal cells to release CD59 by shedding or by transfer of CD59-containing exosomes to the subretinal space where CD59 might be integrated into the drusen [80]. Retinal cells partially or completely depleted of CD59 are susceptible to damage or lysis consecutive to MAC deposition. A role for CD59 in the development of AMD was confirmed in animal models $[85,86]$ and therapeutic attempts were made to provide the RPE of AMD animals with soluble or with membrane-targeted recombinant human CD59 proteins $[85,87]$. For humans, several clinical trials investigating complement inhibitors for AMD patients are ongoing [88]. One of these trials (NCT03144999) investigates whether an adenovirus vector, injected intravitreally, can cause the retinal cells to increase expression of CD59. No results have been published to date.

\section{CD59 and Cancer}

The complement system is fighting tumour cells. It can be activated via all 3 pathways: natural occurring IgM antibodies directed against tumour-specific antigens can bind to tumour cells and start the classical pathway [89, 90]. Mannose-carrying polysaccharide structures on glioma cells activated the lectin pathway
[91]. Virus-transformed B cell lymphoma cells and $\mathrm{HIV}$-infected $\mathrm{T}$ cells may present structures of the virus capsule in the cell membrane which start the alternative pathway $[92,93]$. From the perspective of a tumour cell, it would be advantageous to protect itself by increased expression of CD59 in order to evade lysis by the complement system. Thus, upregulation of complement inhibitory molecules, including CD59, on the surface of tumour cells was interpreted as an evasion mechanism. Squamous cell cancer expressed increased CD59 as compared to normal cells [94]. Increased expression of CD59 on breast cancer correlated with higher numbers of lung metastases and with poorer prognosis [95]. Increased expression of CD59 correlated also with poorer prognosis in oesophageal cancer [96]. Colon cancers with grade III and IV in TMS staging and colon cancer cells with low differentiation showed increased expression of CD59 [97]. It was further observed that increased expression of CD59 made oesophageal cell lines resistant to radiation therapy [96], whereas silencing of CD59 expression with siRNA made the tumour cells more sensitive to chemotherapy [98].

We have seen in a previous section that cytokines can upregulate the expression of CD59 by different tumour cells and cell lines. It is possible that upregulation of CD59 by tumour cells is not a property newly acquired with the malignant transformation. Tumours can activate the immune system which tries to eliminate the malignant cells by antibodies and complement, but also by monocytes, $\mathrm{T}$ cells, and natural killer cells. These leucocytes may release cytokines, including TNF- $\alpha$, IL- 1 , and IFN- $\gamma$, producing an inflammatory milieu which drives tumour cells, but also other cells, to upregulate CD59 expression. Further studies are needed to clarify the role of CD59 in tumour disease and to evaluate the risks and chances of targeted CD59 downregulation in tumour therapy.

\section{Deficiency of CD59 Is Associated with Severe Disease}

\section{Aquired Deficiency of CD59 on Blood Cells}

$\mathrm{PNH}$ is an acquired disease characterised by chronic intravascular and extravascular haemolysis and caused by the inability of PNH cells to control activated complement components (for details see [99]). The released free haemoglobin scavenges nitric oxide (NO) which functions to maintain smooth muscle relaxation. The depletion of NO contributes to smooth muscle dystonia, which causes PNH manifestations like oesophageal spasms, abdominal pain and erectile dysfunction. Activated complement components like C5a, parts of the inner membrane of the lysed erythrocytes, activated platelets, and other factors cause a pro-inflammatory and pro-thrombotic state. Thromboses are a common manifestation of
Weinstock 
Table 3. Signs and results of neurologic, radiologic and pathologic examination of patients with congenital CD59 deficiency

\begin{tabular}{|c|c|c|c|c|c|}
\hline Genetic variant & Ethnic origin & $\begin{array}{l}\text { Number of } \\
\text { patients }\end{array}$ & $\begin{array}{l}\text { Onset of } \\
\text { disease }\end{array}$ & $\begin{array}{l}\text { Major signs observed during } \\
\text { recurrent episodes or at } \\
\text { presentation }\end{array}$ & $\begin{array}{l}\text { Major results of radiologic, neurologic, or } \\
\text { pathologic examination found with } 1 \text { or more } \\
\text { children }\end{array}$ \\
\hline $\begin{array}{l}\text { c.123delC } \\
\text { c.361delG }[11,25]\end{array}$ & Japanese & 1 & 13 years & Haemolysis, cerebral infarctions & - \\
\hline \multirow[t]{5}{*}{$\begin{array}{l}\text { c.266G }>A[108, \\
109]\end{array}$} & \multirow[t]{5}{*}{$\begin{array}{l}\text { North-African } \\
\text { Jewish }\end{array}$} & \multirow[t]{2}{*}{3} & \multirow[t]{2}{*}{ 3-7 months } & \multirow[t]{2}{*}{$\begin{array}{l}\text { Haemolysis, demyelinating } \\
\text { polyneuropathy, weakness }\end{array}$} & $\begin{array}{l}\text { ENMG: results indicative of demyelinating } \\
\text { polyneuropathy }\end{array}$ \\
\hline & & & & & $\begin{array}{l}\text { Biopsies: thinning of myelin, reduction in fibre } \\
\text { number, demyelination }\end{array}$ \\
\hline & & \multirow[t]{3}{*}{2} & \multirow[t]{3}{*}{$3-5$ months } & \multirow{3}{*}{$\begin{array}{l}\text { Flaccid paralysis lower limbs, flaccid } \\
\text { tetraparesis, respiratory insufficiency, } \\
\text { haemolysis }\end{array}$} & $\begin{array}{l}\text { ENMG: results indicative of demyelinating } \\
\text { polyneuropathy }\end{array}$ \\
\hline & & & & & MRI: cortical ischaemic infarctions \\
\hline & & & & & VEP: retinal and optical nerve damage \\
\hline \multirow[t]{4}{*}{ c.146delA [12] } & \multirow[t]{4}{*}{ Turkish } & \multirow[t]{4}{*}{3} & \multirow[t]{4}{*}{$1-7$ months } & \multirow{4}{*}{$\begin{array}{l}\text { Polyneuropathy, tetraparesis, muscle } \\
\text { atrophy, areflexia, bilateral ptosis, } \\
\text { respiratory insufficiency, haemolysis }\end{array}$} & ENMG: reduced conduction velocity \\
\hline & & & & & Demyelinating polyneuropathy \\
\hline & & & & & MRI: haemorrhagic lesions, cerebral infarctions \\
\hline & & & & & $\begin{array}{l}\text { Biopsy: damaged endothelium of brain } \\
\text { vessels, progressive stenoses }\end{array}$ \\
\hline \multirow[t]{3}{*}{ c. $146 \mathrm{~A}>\mathrm{T}[13,111]$} & \multirow[t]{3}{*}{ Turkish } & \multirow[t]{2}{*}{3} & \multirow[t]{2}{*}{ 6-11 months } & \multirow{2}{*}{$\begin{array}{l}\text { Hemiparesis, muscle atrophy, } \\
\text { nystagmus, haemolysis }\end{array}$} & MRI: cerebellar haemorrhagic lesion \\
\hline & & & & & ENMG: axonal neuropathy and demyelination \\
\hline & & 2 & $<10$ years & $\begin{array}{l}\text { Dysarthric speech, horizontal } \\
\text { nystagmus, muscle atrophy, urinary } \\
\text { incontinence }\end{array}$ & $\begin{array}{l}\text { MRI: cortical and cerebellar lesions, } \\
\text { myelopathy }\end{array}$ \\
\hline c.323C >A [14] & Turkish & 1 & 1 year & $\begin{array}{l}\text { Convulsions, hemiparesis, paralysis of } \\
\text { cranial nerves }\end{array}$ & $\begin{array}{l}\text { MRI: thalamic, cerebellar, temporal, spinal } \\
\text { lesions }\end{array}$ \\
\hline c.85T>G [15] & Iranian & 1 & 15 months & $\begin{array}{l}\text { Facial oedema, paraesthesia, } \\
\text { weakness }\end{array}$ & $\begin{array}{l}\text { MRI and ENMG: demyelinating processes } \\
\text { central and peripheral }\end{array}$ \\
\hline
\end{tabular}

MRI, magnetic resonance imaging; ENMG, electroneuromyography; VEP, visually evoked potentials.

$\mathrm{PNH}$ and are the major cause of mortality in $\mathrm{PNH}$ patients [100-102].

Most patients with PNH carry an expanding haematopoietic stem cell clone with an acquired mutation of the phosphatidylinositol glycan class A (PIGA) gene [16]. The PIGA gene is involved in the synthesis of the GPI anchor biosynthesis, and the mutations found in $\mathrm{PNH}$ patients disturb or abolish the production of GPI. In consequence, the expression of GPI-anchored cell membrane proteins including the complement regulatory proteins CD55 and CD59 on erythrocytes, leucocytes and platelets deriving from this stem cell is markedly decreased or completely lacking. The deficiency of CD55 and CD59 makes the cells vulnerable to attacks of the complement system: on healthy cells, CD55 is crucial for the inactivation of the C5-convertases of all 3 pathways and, thereby, counterregulates the formation of pro-inflammatory $\mathrm{C} 5 \mathrm{a}$ and of $\mathrm{C} 5 \mathrm{~b}$, the first component of the MAC. CD59 is the only membrane-bound inhibitor of the MAC and, therefore, lack of CD59 on PNH cells mainly contributes to intravascular haemolysis, the dominant clinical manifestation of PNH, and its sequelae pro-thrombotic state and smooth muscle dystonia [100].

The important role of CD59 for the clinical manifestations of PNH can be estimated by the therapeutic success of the monoclonal antibodies eculizumab and ravulizumab $[103,104]$. Both antibodies bind to C5 and inhibit the cleavage into $\mathrm{C} 5 \mathrm{a}$ and $\mathrm{C} 5 \mathrm{~b}$, i.e., they block the initiation of the terminal pathway, while CD59 blocks the last step of the terminal pathway, the assembly of C8 and C9 molecules. The mechanisms of action of C5-blocking antibodies and of CD59 are different, the effect for the erythrocytes is very similar: the MAC cannot be assembled and the cell will not be lysed. In a study using eculizumab for therapy of PNH patients for an observation period of 26 weeks, intravascular haemolysis was nearly stopped com- 
pletely [17]. When analysing the patients of this and two other studies, it was found that eculizumab reduced thromboembolic events in PNH patients by $85 \%$ [105]. Recent trials have demonstrated non-inferiority of ravulizumab compared to eculizumab across several endpoints. The results of these and other studies on inhibiting the formation of the MAC by C5-blocking antibodies $[104,106,107]$ underscored the role of CD59 deficiency in PNH very clearly.

\section{Congenital CD59 Deficiency}

CD59 is the only membrane-bound inhibitor of the MAC protecting the host's cells when the complement system becomes activated, and we have seen in the previous section that loss of CD59 on only a part of the blood cells can cause severe and life-threatening disease. It is hard to imagine that a complete loss of CD59 on all cells and tissues is compatible with life. Indeed, inherited homozygosity for alleles causing a complete CD59 deficiency causes devastating illness. In 1990, a 22-year-old man with isolated CD59 deficiency was reported [25]. He had a 9-year history of recurrent haemolysis and suffered from hemiplegia after cerebral infarction. His erythrocytes were CD59 deficient but expressed the GPI-anchored protein CD55. Other cells of the patient, such as fibroblasts, keratinocytes, secretory cells of several glands, and vascular endothelium, also did not express CD59. The investigation of the CD59 genes revealed homozygosity for the single nucleotide deletion c.123delC (Table 1), which leads to a frameshift and a premature stop codon [11]. This patient did not show signs of peripheral neuropathy, in contrast to most of the other patients with CD59 deficiency reported thereafter. It lasted until 2013, when the next patients were reported: 5 children between 1 and 4.5 years of age from 4 unrelated families with CD59 deficiency presented with severe chronic inflammatory demyelinating polyneuropathy-like disease [108]. They suffered from progressive muscle wasting accompanied by flaccid paralysis predominantly of the lower limbs. This publication draws the attention of physicians taking care of children with haemolysis and polyneuropathic disorders to the diagnosis of CD59 deficiency. Twelve additional children were diagnosed (Table 3 ), 3 of them post mortem $[109,110]$, and the histories of early deceased relatives who had shown similar symptoms were reviewed $[13,111]$.

Most of these patients had chronic haemolysis and severe neurological disease. Damage of endothelial cells in small vessels was observed [110]; some patients developed acute renal failure $[12,108,109]$. Demyelination of peripheral sensory and motor nerves led to weak reflexes or areflexia, muscle weakness and difficulties or inability to walk, and they required mechanical ventilation $[12,13$, 112]. Further, peripheral hypoaesthesia [14] and urinary incontinence [111] were observed. Demyelinating processes in the central nervous system, ischaemic infarctions or haemorrhagic events impaired the cognitive abilities and mental development including speech. The retina and the optical nerve were involved, and some of the children developed difficulties to swallow. Half of the children developed hemiparesis or tetraparesis. Many of the neurological symptoms exacerbated after vaccination or infection, confirming an important role of complement and of the immune system in CD59 deficiency. When the activation of the immune system had declined, sometimes a partial remission was observed, but in the long run, the disease progressed in all children and 6 of them had died at the time their case was published.

\section{Treatment of Congenital CD59 Deficiency with Eculizumab}

The lessons learned from PNH patients suggested an off-label use of the monoclonal antibody eculizumab in these patients. The first patient treated with eculizumab [12] showed immediate control of haemolysis. At start of therapy, the girl had a flaccid paralysis, could not swallow and needed mechanical ventilation. Six weeks after start of therapy with eculizumab, remission of neurological symptoms started, and after 39 weeks, the 5.5-year-old girl was no longer ventilated, she could swallow and stand without assistance (albeit not walk). Improvement of neurological disease was seen with all patients treated with eculizumab. The ability to swallow returned [112, 113], muscle strength improved [14, 111-113], and some children learned to stand with support $[14,113]$. We hopefully will learn about the long-term effect of C5blocking therapy in these children, including breakthrough events and impaired defence against bacterial infections. We hopefully also will learn to what extent neuroplasticity can reverse damage of the peripheral nerve system and the brain in the children diagnosed so far. Paediatricians are now aware of CD59 deficiency as a possible cause of polyneuropathy and an early start of therapy may ameliorate the severity of the disease in future patients.

\section{Conclusion}

A clear role for CD59 in disease has been established for PNH and congenital CD59 deficiency, where lack of CD59 expression causes severe and life-threatening disease. In congenital CD59 deficiency, children suffer from severe neurological disease and die at a young age. In the recent years, therapy with $\mathrm{C} 5$-blocking monoclonal antibodies was started for most of the reported children, which seemed to stop progression and even improved their status but did not restore their health. No follow-up 
and no reports on long-term efficiency have been published so far.

Surprisingly little evidence for the role of CD59 in other diseases is available. The contribution of CD59 to rheumatoid arthritis and to AMD has been investigated in animal models, but clinical studies have not been published. The investigated cells in these diseases, e.g., patients' synovial cells or retinal cells, are not easily accessible. Mediators released in inflammation or in infectious disease can regulate expression of CD59, presenting the investigators the hen and egg dilemma: is, e.g., downregulation of CD59 cause or consequence of disease? These circumstances make the research complex and time consuming, but the important protective function of CD59 and the lack of substitute inhibitors should encourage research on CD59 and its role in inflammatory diseases.

\section{Acknowledgement}

The author gratefully thanks Sabine Riebschläger for her critical review of the manuscript.

\section{Conflict of Interest Statement}

The author has no conflicts of interest to declare.

\section{Funding Sources}

There were no funding sources.

\section{Author Contributions}

C.W. wrote the manuscript.

\section{References}

1 Lupo D, Li XD, Durand A, Tomizaki T, Cherif-Zahar B, Matassi G, et al. The 1.3-A resolution structure of Nitrosomonas europaea Rh50 and mechanistic implications for NH3 transport by Rhesus family proteins. Proc Natl Acad Sci U S A. 2007;104:19303-8.

2 Olivés B, Mattei MG, Huet M, Neau P, Martial $\mathrm{S}$, Cartron JP, et al. Kidd blood group and urea transport function of human erythrocytes are carried by the same protein. J Biol Chem. 1995;270:15607-10.

3 Smith BL, Preston GM, Spring FA, Anstee DJ, Agre P. Human red cell aquaporin CHIP. I. Molecular characterization of $\mathrm{ABH}$ and Colton blood group antigens. J Clin Invest. 1994;94:1043-9.

4 Helias V, Saison C, Ballif BA, Peyrard T, Takahashi J, Takahashi H, et al. ABCB6 is dispensable for erythropoiesis and specifies the new blood group system Langereis. Nat Genet. 2012;44:170-3.

5 Saison C, Helias V, Ballif BA, Peyrard T, Puy $\mathrm{H}$, Miyazaki T, et al. Null alleles of ABCG2 encoding the breast cancer resistance protein define the new blood group system Junior. Nat Genet. 2012;44:174-7.

6 Horuk R, Chitnis CE, Darbonne WC, Colby TJ, Rybicki A, Hadley TJ, et al. A receptor for the malarial parasite Plasmodium vivax: the erythrocyte chemokine receptor. Science. 1993;261:1182-4

7 Lee S, Zambas ED, Marsh WL, Redman CM. Molecular cloning and primary structure of Kell blood group protein. Proc Natl Acad Sci U S A. 1991;88:6353-7.

8 Spring FA, Gardner B, Anstee DJ. Evidence that the antigens of the Yt blood group system are located on human erythrocyte acetylcholinesterase. Blood. 1992;80:2136-41.

9 El Nemer W, Gane P, Colin Y, Bony V, Rahuel C, Galactéros F, et al. The Lutheran blood group glycoproteins, the erythroid receptors for laminin, are adhesion molecules. J Biol Chem. 1998;273:16686-93.
10 Janeway CA, Travers P, Walport M, Shlomchik MJ. Immunobiology. New York, London: Garland Science Publishing; 2005.

11 Motoyama N, Okada N, Yamashina M, Okada H. Paroxysmal nocturnal hemoglobinuria due to hereditary nucleotide deletion in the HRF20 (CD59) gene. Eur J Immunol. 1992; 22:2669-73.

12 Höchsmann B, Dohna-Schwake C, Kyrieleis HA, Pannicke U, Schrezenmeier H. Targeted therapy with eculizumab for inherited CD59 deficiency. N Engl J Med. 2014;370:90-2.

13 Haliloglu G, Maluenda J, Sayinbatur B, Aumont C, Temucin C, Tavil B, et al. Early-onset chronic axonal neuropathy, strokes, and hemolysis: inherited CD59 deficiency. Neurology. 2015;84:1220-4.

14 Solmaz I, Aytekin ES, Çagdas D, Tan C, Tezcan I, Gocmen R, et al. Recurrent demyelinating episodes as sole manifestation of inherited CD59 deficiency. Neuropediatrics. 2020;51: 206-10.

15 Javadi Parvaneh V, Ghasemi L, Rahmani K, Shiari R, Mesdaghi M, Chavoshzadeh Z, et al. Recurrent angioedema, Guillain-Barré, and myelitis in a girl with systemic lupus erythematosus and CD59 deficiency syndrome. Autoimmun Highlights. 2020;11:9.

16 Takeda J, Miyata T, Kawagoe K, Iida Y, Endo Y, Fujita T, et al. Deficiency of the GPI anchor caused by a somatic mutation of the PIG-A gene in paroxysmal nocturnal hemoglobinuria. Cell. 1993;73:703-11.

17 Hillmen P, Young NS, Schubert J, Brodsky RA, Socié G, Muus P, et al. The complement inhibitor eculizumab in paroxysmal nocturnal hemoglobinuria. N Engl J Med. 2006;355: 1233-43.

18 Anliker M, von Zabern I, Höchsmann B, Kyrieleis H, Dohna-Schwake C, Flegel WA, et al. A new blood group antigen is defined by anti-CD59, detected in a CD59-deficient patient. Transfusion. 2014;54:1817-22.
19 International Society of Blood Transfusion (ISBT) [Internet]. Classification in Blood Group Terminology. [cited 2021 Aug 20]. Available from: https: //www.isbtweb.org/fileadmin/ user_upload/files-2015/red\%20cells/blood\%20 group $\% 20$ allele $\% 20$ terminology/ISBT $\% 20$ Guidelines $\% 20 \mathrm{Naming} \% 20 \mathrm{Blood} \% 20$ Group\%20Alleles\%20v2.0\%20110914.pdf.

20 International Society of Blood Transfusion (ISBT) [Internet]. Blood Group System CD59. [cited 2021 Aug 20]. Available from: https://www.isbtweb.org/fileadmin/user_upload/_ISBT_035__CD59_blood_group_alleles_v2.0_01-MAR-2020.pdf.

21 Weinstock C, Anliker M, von Zabern I. An update on the CD59 blood group system. Immunohematology. 2019;35:7-8.

22 Huang Y, Fedarovich A, Tomlinson S, Davies C. Crystal structure of CD59: implications for molecular recognition of the complement proteins $\mathrm{C} 8$ and $\mathrm{C} 9$ in the membrane-attack complex. Acta Crystallogr D Biol Crystallogr. 2007;63:714-21.

23 Karbian N, Eshed-Eisenbach Y, Tabib A, Hoizman H, Morgan BP, Schueler-Furman $\mathrm{O}$, et al. Molecular pathogenesis of human CD59 deficiency. Neurol Genet. 2018;4:e280.

$24 \mathrm{Li} \mathrm{XF}$, Lin FQ, Li JP. Identification of c.238 A> G (p.Arg80Gly) of CD59 blood group gene. Transfusion. 2018;58:3033-4.

25 Yamashina M, Ueda E, Kinoshita T, Takami $\mathrm{T}$, Ojima A, Ono $\mathrm{H}$, et al. Inherited complete deficiency of 20-kilodalton homologous restriction factor (CD59) as a cause of paroxysmal nocturnal hemoglobinuria. N Engl J Med. 1990;323:1184-9.

26 Takahashi K, Ip WE, Michelow IC, Ezekowitz RA. The mannose-binding lectin: a prototypic pattern recognition molecule. Curr Opin Immunol. 2006;18:16-23.

27 Vogt W, Schmidt G, Von Buttlar B, Dieminger L. A new function of the activated third component of complement: binding to C5, an essential step for C5 activation. Immunology. 1978;34:29-40. 
28 Mannes M, Dopler A, Zolk O, Lang SJ, Halbgebauer R, Höchsmann B, et al. Complement inhibition at the level of C3 or C5: mechanistic reasons for ongoing terminal pathway activity. Blood. 2021;137:443-55.

29 Kirschfink M. Controlling the complement system in inflammation. Immunopharmacology. 1997;38:51-62.

30 Schmidt CQ, Lambris JD, Ricklin D. Protection of host cells by complement regulators. Immunol Rev. 2016;274:152-71.

31 Iida K, Nussenzweig V. Functional properties of membrane-associated complement receptor CR1. J Immunol. 1983;130:1876-80.

32 Burge J, Nicholson-Weller A, Austen KF. Isolation of C4-binding protein from guinea pig plasma and demonstration of its function as a control protein of the classical complement pathway C3 convertase. J Immunol. 1981;126: 232-5.

33 Seya T, Turner JR, Atkinson JP. Purification and characterization of a membrane protein (gp45-70) that is a cofactor for cleavage of C3b and C4b. J Exp Med. 1986;163:837-55.

34 Schönermark S, Filsinger S, Berger B, Hänsch GM. The C8-binding protein of human erythrocytes: interaction with the components of the complement-attack phase. Immunology. 1988;63:585-90.

35 Blaas P, Berger B, Weber S, Peter HH, Hänsch GM. Paroxysmal nocturnal hemoglobinuria. Enhanced stimulation of platelets by the terminal complement components is related to the lack of C8bp in the membrane. J Immunol. 1988;140:3045-51.

36 Li K, Fazekasova H, Wang N, Sagoo P, Peng Q, Khamri W, et al. Expression of complement components, receptors and regulators by human dendritic cells. Mol Immunol. 2011;48:1121-7.

37 Zelek WM, Watkins LM, Howell OW, Evans R, Loveless S, Robertson NP, et al. Measurement of soluble CD59 in CSF in demyelinating disease: Evidence for an intrathecal source of soluble CD59. Mult Scler. 2019;25:523-31.

38 Vogt SD, Barnum SR, Curcio CA, Read RW Distribution of complement anaphylatoxin receptors and membrane-bound regulators in normal human retina. Exp Eye Res. 2006;83: 834-40.

39 Singhrao SK, Neal JW, Rushmere NK, Morgan BP, Gasque P. Differential expression of individual complement regulators in the brain and choroid plexus. Lab Invest. 1999;79: 1247-59.

40 McGeer PL, Walker DG, Akiyama H, Kawamata T, Guan AL, Parker CJ, et al. Detection of the membrane inhibitor of reactive lysis (CD59) in diseased neurons of Alzheimer brain. Brain Res. 1991;544:315-9.

41 Nose M, Katoh M, Okada N, Kyogoku M, Okada H. Tissue distribution of HRF20, a novel factor preventing the membrane attack of homologous complement, and its predominant expression on endothelial cells in vivo. Immunology. 1990;70:145-9.

42 Miyaji K, Paul F, Shahrizaila N, Umapathi T, Yuki N. Complement regulatory proteins (CD46, 55 and 59) expressed on Schwann cells: immune targets in demyelinating neuropathies? J Neuroimmunol. 2014;276:172-4.
43 Thurman JM, Renner B, Kunchithapautham K, Ferreira VP, Pangburn MK, Ablonczy Z, et al. Oxidative stress renders retinal pigment epithelial cells susceptible to complementmediated injury. J Biol Chem. 2009;284: 16939-47.

44 Juel HB, Kaestel C, Folkersen L, Faber C, Heegaard NH, Borup R, et al. Retinal pigment epithelial cells upregulate expression of complement factors after co-culture with activated T cells. Exp Eye Res. 2011;92:180-8.

45 Mason JC, Lidington EA, Yarwood H, Lublin DM, Haskard DO. Induction of endothelial cell decay-accelerating factor by vascular endothelial growth factor: a mechanism for cytoprotection against complement-mediated injury during inflammatory angiogenesis. Arthritis Rheum. 2001;44:138-50.

46 Lidington EA, Haskard DO, Mason JC. Induction of decay-accelerating factor by thrombin through a protease-activated receptor 1 and protein kinase $\mathrm{C}$-dependent pathway protects vascular endothelial cells from complement-mediated injury. Blood. 2000; 96:2784-92.

47 Venneker GT, Das PK, Meinardi MM, van MJ, van Veen HA, Bos JD, et al. Glycosylphosphatidylinositol (GPI)-anchored membrane proteins are constitutively down-regulated in psoriatic skin. J Pathol. 1994;172:189-97.

48 Nangaku M. Complement regulatory proteins in glomerular diseases. Kidney Int. 1998; 54:1419-28.

49 Rautemaa R, Meri S. Protection of gingival epithelium against complement-mediated damage by strong expression of the membrane attack complex inhibitor protectin (CD59). J Dent Res. 1996;75:568-74.

50 Tandon N, Morgan BP, Weetman AP. Expression and function of membrane attack complex inhibitory proteins on thyroid follicular cells. Immunology. 1992;75:372-7.

51 Pasch MC, Bos JD, Daha MR, Asghar SS. Transforming growth factor-beta isoforms regulate the surface expression of membrane cofactor protein (CD46) and CD59 on human keratinocytes [corrected]. Eur J Immunol. 1999;29:100-8.

52 Davies ME, Horner A, Loveland BE, McKenzie IF. Upregulation of complement regulators MCP (CD46), DAF (CD55) and protectin (CD59) in arthritic joint disease. Scand J Rheumatol. 1994;23:316-21.

53 Guc D, Gulati P, Lemercier C, Lappin D, Birnie GD, Whaley K. Expression of the components and regulatory proteins of the alternative complement pathway and the membrane attack complex in normal and diseased synovium. Rheumatol Int. 1993;13:139-46.

54 Navenot JM, Villanova M, Lucas-Héron B, Malandrini A, Blanchard D, Louboutin JP. Expression of CD59, a regulator of the membrane attack complex of complement, on human skeletal muscle fibers. Muscle Nerve. 1997;20:92-6.

55 Füst A, Pállinger E, Stündl A, Kovács E, Imre $\mathrm{L}$, Tóth S, et al. Both freshly prepared and frozen-stored amniotic membrane cells express the complement inhibitor CD59. Scientific WorldJournal. 2012;2012:815615.
56 Ueda M, Sato Y, Horie A, Tani H, Miyazaki Y, Okunomiya A, et al. Endovascular trophoblast expresses CD59 to evade complementdependent cytotoxicity. Mol Cell Endocrinol. 2019;490:57-67.

57 Issitt PD. Antibody mediated red cell destruction following the transfusion of incompatible blood: a review. Med Lab Technol. 1973; 30:95-103.

58 Christmas SE, de la Mata Espinosa CT, Halliday D, Buxton CA, Cummerson JA, Johnson PM. Levels of expression of complement regulatory proteins CD46, CD55 and CD59 on resting and activated human peripheral blood leucocytes. Immunology. 2006;119:522-8.

59 Mahtout H, Curt S, Chandad F, Rouabhia M, Grenier D. Effect of periodontopathogen lipopolysaccharides and proinflammatory cytokines on CD46, CD55, and CD59 gene/protein expression by oral epithelial cells. FEMS Immunol Med Microbiol. 2011;62:295-303.

60 Lepik K, Annilo T, Kukuskina V, Kisand K, Kutalik Z, Peterson P, et al. C-reactive protein upregulates the whole blood expression of C. PLoS Comput Biol. 2017;13:e1005766.

61 Bjoerge L, Jensen TS, Ulvestad E, Vedeler CA, Matre R. The influence of tumour necrosis factor-alpha, interleukin-1 beta and interferon-gamma on the expression and function of the complement regulatory protein CD59 on the human colonic adenocarcinoma cell line HT29. Scand J Immunol. 1995;41:350-6.

62 Spiller OB, Criado-García O, Rodríguez De Córdoba S, Morgan BP. Cytokine-mediated up-regulation of CD55 and CD59 protects human hepatoma cells from complement attack. Clin Exp Immunol. 2000;121:234-41.

63 Moutabarrik A, Nakanishi I, Namiki M, Hara T, Matsumoto M, Ishibashi M, et al. Cytokine-mediated regulation of the surface expression of complement regulatory proteins, CD46(MCP), CD55(DAF), and CD59 on human vascular endothelial cells. Lymphokine Cytokine Res. 1993;12:167-72.

64 Schmitt CA, Schwaeble W, Wittig BM, Meyer zum Büschenfelde KH, Dippold WG. Expression and regulation by interferon-gamma of the membrane-bound complement regulators CD46 (MCP), CD55 (DAF) and CD59 in gastrointestinal tumours. Eur J Cancer. 1999; 35:117-24.

65 Koch N, Jung M, Sabat R, Krätzschmar J, Döcke WD, Asadullah K, et al. IL-10 protects monocytes and macrophages from complement-mediated lysis. J Leukoc Biol. 2009;86: 155-66.

66 Struglics A, Okroj M, Swärd P, Frobell R, Saxne T, Lohmander LS, et al. The complement system is activated in synovial fluid from subjects with knee injury and from patients with osteoarthritis. Arthritis Res Ther. 2016;18:223.

67 Konttinen YT, Ceponis A, Meri S, Vuorikoski A, Kortekangas P, Sorsa T, et al. Complement in acute and chronic arthritides: assessment of C3c, C9, and protectin (CD59) in synovial membrane. Ann Rheum Dis. 1996;55:888-94.

68 Linton SM, Morgan BP. Complement activation and inhibition in experimental models of arthritis. Mol Immunol. 1999;36:905-14. 
69 Okroj M, Heinegård D, Holmdahl R, Blom AM. Rheumatoid arthritis and the complement system. Ann Med. 2007;39:517-30.

70 Wang Q, Rozelle AL, Lepus CM, Scanzello CR, Song JJ, Larsen DM, et al. Identification of a central role for complement in osteoarthritis. Nat Med. 2011;17:1674-9.

71 Williams AS, Mizuno M, Richards PJ, Holt DS, Morgan BP. Deletion of the gene encoding CD59a in mice increases disease severity in a murine model of rheumatoid arthritis. Arthritis Rheum. 2004;50:3035-44.

72 Mizuno M, Nishikawa K, Goodfellow RM, Piddlesden SJ, Morgan BP, Matsuo S. The effects of functional suppression of a membrane-bound complement regulatory protein, CD59, in the synovial tissue in rats. Arthritis Rheum. 1997;40:527-33.

73 Fraser DA, Harris CL, Williams AS, Mizuno M, Gallagher S, Smith RA, et al. Generation of a recombinant, membrane-targeted form of the complement regulator CD59: activity in vitro and in vivo. J Biol Chem. 2003;278: 48921-7.

74 Kinderlerer AR, Steinberg R, Johns M, Harten SK, Lidington EA, Haskard DO, et al. Statininduced expression of CD59 on vascular endothelium in hypoxia: a potential mechanism for the anti-inflammatory actions of statins in rheumatoid arthritis. Arthritis Res Ther. 2006;8:R130.

75 Lim LS, Mitchell P, Seddon JM, Holz FG, Wong TY. Age-related macular degeneration. Lancet. 2012;379:1728-38.

76 Singh A. Systemic changes in neovascular age-related macular degeneration. Dan Med J. 2014;61:B4872.

77 Ardeljan D, Chan CC. Aging is not a disease: distinguishing age-related macular degeneration from aging. Prog Retin Eye Res. 2013;37: 68-89.

78 Anderson DH, Mullins RF, Hageman GS, Johnson LV. A role for local inflammation in the formation of drusen in the aging eye. Am J Ophthalmol. 2002;134:411-31.

79 Mullins RF, Schoo DP, Sohn EH, FlammeWiese MJ, Workamelahu G, Johnston RM, et al. The membrane attack complex in aging human choriocapillaris: relationship to macular degeneration and choroidal thinning. Am J Pathol. 2014;184:3142-53.

80 Ebrahimi KB, Fijalkowski N, Cano M, Handa JT. Decreased membrane complement regulators in the retinal pigmented epithelium contributes to age-related macular degeneration. J Pathol. 2013;229:729-42.

81 Lueck K, Wasmuth S, Williams J, Hughes TR, Morgan BP, Lommatzsch A, et al. Sub-lytic C5b-9 induces functional changes in retinal pigment epithelial cells consistent with agerelated macular degeneration. Eye (Lond). 2011:25:1074-82.

82 Haines JL, Hauser MA, Schmidt S, Scott WK, Olson LM, Gallins P, et al. Complement factor $\mathrm{H}$ variant increases the risk of age-related macular degeneration. Science. 2005;308: 419-21.

83 Edwards AO, Ritter R III, Abel KJ, Manning A, Panhuysen C, Farrer LA. Complement factor $\mathrm{H}$ polymorphism and age-related macular degeneration. Science. 2005;308:421-4.
84 Hageman GS, Anderson DH, Johnson LV, Hancox LS, Taiber AJ, Hardisty LI, et al. A common haplotype in the complement regulatory gene factor $\mathrm{H}(\mathrm{HF} 1 / \mathrm{CFH})$ predisposes individuals to age-related macular degeneration. Proc Natl Acad Sci U S A. 2005;102: 7227-32.

85 Bora NS, Kaliappan S, Jha P, Xu Q, Sivasankar $\mathrm{B}$, Harris CL, et al. CD59, a complement regulatory protein, controls choroidal neovascularization in a mouse model of wet-type agerelated macular degeneration. J Immunol. 2007;178:1783-90.

86 Schnabolk G, Beon MK, Tomlinson S, Rohrer B. New insights on complement inhibitor CD59 in mouse laser-induced choroidal neovascularization: mislocalization after injury and targeted delivery for protein replacement. J Ocul Pharmacol Ther. 2017;33:400-11.

87 Bora NS, Jha P, Lyzogubov VV, Kaliappan S, Liu J, Tytarenko RG, et al. Recombinant membrane-targeted form of CD59 inhibits the growth of choroidal neovascular complex in mice. J Biol Chem. 2010;285:33826-33.

88 Halawa OA, Lin JB, Miller JW, Vavvas DG. A review of completed and ongoing complement inhibitor trials for geographic atrophy secondary to age-related macular degeneration. J Clin Med. 2021:10(12):2580.

89 Devarapu SK, Mamidi S, Plöger F, Dill O, Blixt O, Kirschfink M, et al. Cytotoxic activity against human neuroblastoma and melanoma cells mediated by IgM antibodies derived from peripheral blood of healthy donors. Int J Cancer. 2016;138:2963-73.

90 Brändlein S, Pohle T, Ruoff N, Wozniak E, Müller-Hermelink HK, Vollmers HP. Natural IgM antibodies and immunosurveillance mechanisms against epithelial cancer cells in humans. Cancer Res. 2003;63:7995-8005.

91 Fujita T, Taira S, Kodama N, Matsushita M, Fujita T. Mannose-binding protein recognizes glioma cells: in vitro analysis of complement activation on glioma cells via the lectin pathway. Jpn J Cancer Res. 1995;86:187-92.

92 Budzko DB, Lachmann PJ, McConnell I. Activation of the alternative complement pathway by lymphoblastoid cell lines derived from patients with Burkitt's lymphoma and infectious mononucleosis. Cell Immunol. 1976;22: 98-109.

93 Yefenof E, Asjö B, Klein E. Alternative complement pathway activation by HIV infected cells: C3 fixation does not lead to complement lysis but enhances NK sensitivity. Int Immunol. 1991;3:395-401.

94 Ravindranath NM, Shuler C. Expression of complement restriction factors (CD46, CD55 \& CD59) in head and neck squamous cell carcinomas. J Oral Pathol Med. 2006;35:560-7.

95 Ouyang Q, Zhang L, Jiang Y, Ni X, Chen S, Ye $\mathrm{F}$, et al. The membrane complement regulatory protein CD59 promotes tumor growth and predicts poor prognosis in breast cancer. Int J Oncol. 2016;48:2015-24.

96 Zhou Y, Chu L, Wang Q, Dai W, Zhang X, Chen J, et al. CD59 is a potential biomarker of esophageal squamous cell carcinoma radioresistance by affecting DNA repair. Cell Death Dis. 2018;9:887.
97 Shang Y, Chai N, Gu Y, Ding L, Yang Y, Zhou J, et al. Systematic immunohistochemical analysis of the expression of CD46, CD55, and CD59 in colon cancer. Arch Pathol Lab Med. 2014;138:910-9.

98 Yin $\mathrm{H}, \mathrm{Li}$ C, Wang S, Guo Q, Ren X, Jiang G. Silencing of CD59 enhanced the sensitivity of HT29 cells to 5-fluorouracil and oxaliplatin. J Infect Chemother. 2015;21:8-15.

99 Brodsky RA. Paroxysmal nocturnal hemoglobinuria. Blood. 2014;124(18):2804-11.

100 Schrezenmeier H, Muus P, Socié G, Szer J, Urbano-Ispizua A, Maciejewski JP, et al. Baseline characteristics and disease burden in patients in the International Paroxysmal Nocturnal Hemoglobinuria Registry. Haematologica. 2014;99:922-9.

101 Schrezenmeier H, Röth A, Araten DJ, Kanakura Y, Larratt L, Shammo JM, et al. Baseline clinical characteristics and disease burden in patients with paroxysmal nocturnal hemoglobinuria $(\mathrm{PNH})$ : updated analysis from the International PNH Registry. Ann Hematol. 2020;99:1505-14.

102 Schmidt CQ, Schrezenmeier H, Kavanagh D. Complement and the prothrombotic state. Blood. 2021 Aug;blood.2020007206.

103 Brodsky RA, Young NS, Antonioli E, Risitano AM, Schrezenmeier H, Schubert J, et al. Multicenter phase 3 study of the complement inhibitor eculizumab for the treatment of patients with paroxysmal nocturnal hemoglobinuria. Blood. 2008;111:1840-7.

104 Lee JW, Sicre de Fontbrune F, Wong Lee Lee LL, Pessoa V, Gualandro S, Füreder W, et al. Ravulizumab (ALXN1210) vs eculizumab in adult patients with PNH naive to complement inhibitors: the 301 study. Blood. 2019; 133:530-9.

105 Hillmen P, Muus P, Duhrsen U, Risitano AM, Schubert J, Luzzatto L, et al. Effect of the complement inhibitor eculizumab on thromboembolism in patients with paroxysmal nocturnal hemoglobinuria. Blood. 2007; 110:4123-8.

106 Röth A, Nishimura JI, Nagy Z, Gaál-Weisinger J, Panse J, Yoon SS, et al. The complement $\mathrm{C} 5$ inhibitor crovalimab in paroxysmal nocturnal hemoglobinuria. Blood. 2020;135: 912-20.

107 Schrezenmeier H, Kulasekararaj A, Mitchell L, Sicre de FF, Devos T, Okamoto S, et al. One-year efficacy and safety of ravulizumab in adults with paroxysmal nocturnal hemoglobinuria naive to complement inhibitor therapy: open-label extension of a randomized study. Ther Adv Hematol. 2020;11: 2040620720966137.

108 Nevo Y, Ben-Zeev B, Tabib A, Straussberg R, Anikster Y, Shorer Z, et al. CD59 deficiency is associated with chronic hemolysis and childhood relapsing immune-mediated polyneuropathy. Blood. 2013;121:12935.

109 Ben-Zeev B, Tabib A, Nissenkorn A, Garti BZ, Gomori JM, Nass D, et al. Devastating recurrent brain ischemic infarctions and retinal disease in pediatric patients with CD59 deficiency. Eur J Paediatr Neurol. 2015;19: 688-93. 
110 Klemann C, Kirschner J, Ammann S, Urbach $\mathrm{H}$, Moske-Eick O, Zieger B, et al. CD59 deficiency presenting as polyneuropathy and Moyamoya syndrome with endothelial abnormalities of small brain vessels. Eur J Paediatr Neurol. 2018;22:870-7.

111 Yuksel D, Oguz KK, Azapagasi E, Kesici S, Cavdarli B, Konuskan B, et al. Uncontrolled inflammation of the nervous system: inherited CD59 deficiency. Neurol Clin Pract. 2018;8:e18-e20.
112 Ardicli D, Taskiran EZ, Kosukcu C, Temucin C, Oguz KK, Haliloglu G, et al. Neonatalonset recurrent Guillain-Barre syndromelike disease: clues for inherited CD59 deficiency. Neuropediatrics. 2017;48:477-81.

113 Mevorach D, Reiner I, Grau A, Ilan U, Berkun Y, Ta-Shma A, et al. Therapy with eculizumab for patients with CD59 p.Cys89Tyr mutation. Ann Neurol. 2016;80:70817.
114 Zalman LS, Wood LM, Müller-Eberhard HJ. Inhibition of antibody-dependent lymphocyte cytotoxicity by homologous restriction factor incorporated into target cell membranes. J Exp Med. 1987;166:947-55.

115 Sayama K, Zalman LS, Müller-Eberhard HJ, Gigli I. Expression and modulation of homologous restriction factor (HRF) on peripheral white blood cells. Trans Assoc Am Physicians. 1988;101:270-81. 